СУЧАСНИЙ СТАН ПРОБЛЕМИ СИНДРОМУ БОЛЬОВОЇ ДИСФУНКЦІЇ (КЛІНІЧНА КАРТИНА ТА ПІДХОДИ ДО ЛІКУВАННЯ). ОГЛЯД ЛІТЕРАТУРИ

\title{
CURRENT STATE OF THE PAIN DYSFUNCTION SYNDROME PROBLEM (CLINICAL PRESENTATION AND TREATMENT APPROACHES). LITERATURE REVIEW
}

УдК 159.923

DOI https://doi.org/10.32843/26635208.2021.31.23

\section{Мінчук P.I.}

аспірант кафедри клінічної психології ТОВ «Київський інститут сучасної психології та психотерапії»

\begin{abstract}
Світ прискорився, прогрес не стоїть на місці, але від 40 до 80\% населення, як $і$ раніше, страждають від больового синдрому спини. Цей фракт свідчить про те, що дотепер так і не знайдено оптимального підходу щодо діагностики та лікування цієї проблеми.

Підходи, що існують сьогодні, розглядають проблему больового синдрому в спині із суто соматичного боку, іноді до ії лікування підключаються спеціалісти з остеопатії, дуже рідко ми стикаємося з психологічною допомогою при болях у спині. Крім того, чі підходи використовуються окремо один від одного, що не допомагає пацієнту, а, навпаки, пролонгує шлях до його одужання.

Саме тому існує нагальна потреба пошуку нових лікувальних тактик, а можливо, зміни класичного підходу до терапії болю в спині та розгляду його не лише як соматичної проблеми, а враховувати і його психологічні аспекти, підключати остеопатичний підхід до системи допомоги. Варто зазначити, що, попри велику кількість досліджень у психосоматичному підході щодо больового синдрому спини, дотепер немає єдиного загальноприйнятого розуміння, що потребує подальшого вивчення.

Також $є$ дефіiцит розуміння психологічних наслідків больового синдрому в спині, його впливу на особистість, фракторів ризику його виникнення. Не описано особливості особистості, притаманні пацієнтам із цим синдромом.

Саме тому в статті розглянуто проблеми діагностики та лікування больового синдрому в спині, проаналізовано наявні дані щодо його психологічних наслідків і фракторів ризику його виникнення, описано соматичні, остеопатичні та психокорекційні методи, які колись було використано для допомоги пацієнтам із цією проблемою. Також здійснено спробу щодо пошуку нових підходів до терапії больового синдрому в спині та інтеграції їх у загальну систему допомоги
\end{abstract}

з використанням психоостеосоматичного підходу.

Ключові слова: больовий синдром спини, діагностика, лікування, фрактори ризику, психоостеосоматичний метод.

The world has accelerated, progress is not standing still, but 40 to $80 \%$ of the population still suffers from back pain. This fact indicates that no optimal approach has been found to the diagnosis and treatment of this problem so far.

Current approaches address the problem of back pain from a purely somatic point of view, sometimes osteopaths are involved in its treatment, and very rarely we encounter psychological help for back pain. In addition, these approaches are used separately from each other, which does not help the patient but rather prolongs the path to recovery.

That is why there is an urgent need to find new treatment tactics, and possibly change the classical approach to the treatment of back pain and consider it not only as a somatic problem, but also to take into account its psychological aspects and connect osteopathic approach to the care system. It should be noted that despite the large number of studies in the psychosomatic approach to back pain, there is still no single common understanding that needs further study. There is also a deficit in understanding the psychological consequences of back pain, its impact on the personality, risk factors for its occurrence. The personality traits inherent in patients with this syndrome are not described.

That is why this article discusses the problems of diagnosis and treatment of back pain, analyzes existing data on its psychological consequences and risk factors, describes somatic, osteopathic and psycho-corrective methods that were once used to help patients with this problem. An attempt was also made to find new approaches to the treatment of back pain and integrate them into the general care system using a psychoosteosomatic approach

Key words: Back pain syndrome, diagnosis, treatment, risk factors, psychoosteosomatic method.
Більшість людей як мінімум один раз у житті стикалася з проблемою болю в спині. Він може виникати після динамічних фізичних навантажень, за тривалого перебування в статичній позі, після серйозних травм або ідіопатично, тобто просто так.

Згідно з даними ВООЗ, больовий синдром у спині - найбільш поширена проблема звернення щодо медичної допомоги [1].

Біль у нижній частині спини - одна з найчастіших причин звернення до лікаря, цей стан $€$ лідируючою причиною втрати працездатності серед населення.

Основні причини болю в спині можна розділити на дві групи: вертеброгенні й невертеброгенні. Більшості пацієнтів із вертеброгенними болями в спині ставиться діагноз:
- грижа диска;

- спондилез;

- остеофіти;

- сакралізація, люмбалізація;

- зміни в міжхребцевих (фасеточних) суглобах:

- анкілозируючий спондиліт;

- спинальний стеноз;

- нестабільність хребцево-рухового сегмента з утворенням спондилолістезу;

- остеопороз;

- хвороба Бєхтєрева;

- функціональні порушення в міжхребцевих суглобах;

- остеохондроз.

Наступна теорія описує виникнення больового синдрому спини невертеброгенної етіології: 
- міофасціальний синдром;

- фасеточний синдром;

- вісцеро-соматичний рефлекс (синдром дзеркального відображеного болю в спині внаслідок порушення роботи органів ШКТ).

За тривалістю больового синдрому виділяють фази: гостру (<4 тижнів), підгостру (від 4 до 12 тижнів) і хронічну (> 12 тижнів). Кожна друга людина протягом життя хоча б раз стикається з епізодом болю в спині. У 3-10\% людей біль у спині набуває хронічного стану. у 90\% випадків біль у спині - це скелетно-м'язовий біль [2-5].

Біль - це наш «пес-охоронець», це чуттєвий досвід, що допомагає виживанню і $є$ еволюційно важливий. Він формується в голові людини й завжди залежить від контексту. Якщо він загрозливий, то біль посилюється. Наприклад, при травмі мізинця на нозі футболіст буде відчувати біль сильніше, ніж піаніст, оскільки для футболіста травмування пальця несе загрозливий контекст. Так працює фізіологія болю [6; 7].

У 2018 році в серії статей про цю проблему в британському медичному журналі The Lancet зазначали, що в один момент півмільярда людей у цьому світі відчувають біль у спині. За даними ВООЗ, 70\% людей стикаються із цією проблемою, а в 10\% біль у спині стає хронічним [8].

Больовий синдром істотно змінює весь соціальний розвиток людини, змінює їі можливості в здійсненні різних видів діяльності, призводить до обмеження кола контактів, загальної зміни місця в житті. У зв'язку з цим досить часто спостерігаються психологічні наслідки больового синдрому, такі як психоемоційна лабільність, кволість, апатія, підвищена вимогливість, образливість, зниження вольової активності, обмеження кола інтересів, порушення цілеспрямованої діяльності, збіднення загального психічного складу [9].

У літературі часто зустрічаються спроби знайти причину больового синдрому в спині в порушеннях формування хребта, тобто суто соматичний підхід до цієї проблеми.

Згідно з однією з теорій, формування больового синдрому спини дорослої людини може формуватися ще в перинатальний період. Опірно-рухові дисфункції формуються разом із плодом в період ембріогенезу.

Описано, що вроджені зміни виникають унаслідок відхилень внутрішньоутробного розвитку, наявності гена кривизни у формуванні лордо-кіфоз-лордоз або травми плода під час пологів. Це хребці клиновидної форми, сполучнотканинна дисплазія, вивих атланта (1-го шийного хребця), міотонічні синдроми (кривошия тощо). На частку вроджених відхилень припадає не більше $10 \%$ усіх поразок $[10 ; 11]$.
З остеопатичної точки зору якщо спостерігається вивих або підвивих атланта і зміна його положення відносно аксису (2-го шийного) і по принципу доміно інші тіла й відростки з фасетками будуть адаптуватися під зміну положення одного тіла хребця. У перспективі це може призвести до скаліотичної дуги й больового синдрому в ранньому віці [12].

Через порушення нормального стану шийного відділу хребта часто можна спостерігати зниження надходження крові в головний мозок, що спричиняє гіпоксію, порушення діяльності моторної кори та мозкових оболоHOK [13].

Повертаючись до питання больового синдрому невертеброгенної етіології, під міофасціальним синдромом розуміють утворені в товщі м'яза міофасціальні тригерні точки і блоки.

У товщі м'яза знаходиться велика кількість дрібних нервових закінчень і судин, які можуть подразнюватися через механічного стиснення, що й викликає почуття болю, відчуття «защемлення» в спині.

У ЦНС формується вогнища і подразнення на вегетативно-психічному й соматичному рівнях $[14 ; 15]$.

Згідно зі статистикою, частота болю в спині внаслідок фасеточного синдрому становить $15-40 \%$ [16].

Вісцеро-соматичний рефлекс виникає внаслідок тривалого перенапруження, що, у свою чергу, призводить до підвищення концентрації соляної кислоти й вироблення шлункового ферменту гастрину 17, що є причиною виникнення виразки шлунка і 12-палої кишки, у вигляді компенсації відбувається фасилітація (блок) сегмента хребетного стовпа на рівні місця прикріплення шлунка і 12-типалої кишки до хребта. У результаті виникає біль у спині, що має в основі порушення органів травлення $[17 ; 18]$.

Коли біль систематично дає про себе знати, формується рефлекторна больова дуга від, умовно кажучи, джерела болю до мозку. У мозку, у свою чергу, формується нейрофізіологічний больовий шип (аксон + дендрит + нейромедіатор + синапс $=$ біль) .

У цей момент біль уже існує в голові, людина починає весь час чекати біль, навіть коли його немає, а коли він з'являється, то він посилюється більше, ніж є насправді. Біль стає суб'єктивним і заважає жити, працювати, насолоджуватися життям. Це тригер, який кричить і ніяк не замовкає.

Часто м'язовий тригер може спричиняти біль, але еволюційно напруження м'язів спини має захисний характер: захист еластичного міжхребцевого диска від надмірного навантаження, але в деяких випадках цей механізм може шкодити. 
Далі соматичний біль викликає психоемоційні порушення. Механізм психологічного патогенезу больового синдрому спини виглядає як катастрофізація болю (драматичне, дисфункціональне сприйняття болю і його наслідків для життя), кінезіофобію (страх пацієнта підвищувати фізичну активність, займатися фізичними вправами), «обмежувальна, «больова» поведінка (вироблені пацієнтом дезадаптивні моделі поведінки, які насправді тільки погіршують його стан), а іноді симптоми тривоги й депресії, порушення сну [19; 20].

Унаслідок порушення опорно-рухового апарату й виникнення больових відчуттів різного патогонезу супутні негативні думки пацієнта (катастрофізація болю) викликають негативні емоції (тривога, сум, гнів, злість), які, у свою чергу, підсилюють біль і сприяють розвитку дезадаптувальної поведінки (зниження повсякденної активності, надлишковий прийом знеболюючих препаратів, проходження повторних медичних обстежень і консультацій за відсутності органічної патології, звільнення з роботи тощо) [21].

Формується так зване «порочне коло»: негативна думка негативна емоція біль дезадаптувальна поведінка і знову негативна думка [22].

За результатами нейрофізіологічних досліджень і функціональної магнітно-резонансної томографії (МРТ), у пацієнтів з больовим синдромом негативні думки викликають посилення сприйняття болю, підвищення активності структур головного мозку, відповідальних за емоційне сприйняття болю [23].

Таким чином, ми підійшли до розгляду проблеми больового синдрому в спині з позиції психосоматичного підходу.

Загалом проблема тісного взаємозв'язку психічного й соматичного вивчається протягом кількох століть, із часів Гіппократа й Арістотеля.

У 1818 році німецький лікар із Лейпцига Я. Хайнрот увів термін «психосоматичний». Йому належали слова: «Причини безсоння зазвичай психічно-соматичні, проте кожна життєва сфера може сама по собі бути достатньою їй підставою».

«Психосоматика (грец. Psyche - душа, soma - тіло) - напрям у медицині і психології, що займається вивченням впливу психологічних факторів на виникнення й подальшу динаміку соматичних захворювань [24].

Психосоматичні захворювання - це біль і страждання душі, які не знайшли іншого виходу, крім як через тіло, це розповідь душі про себе, а найчастіше її крик.

Часто-густо цей «крик» настільки гучний, що вночі неможливо спати, 80\% пацієнтів із хронічним болем мають в анамнезі психотравму, або «психологічне погіршення». Саме тому в лікуванні хронічних хворих необхідна не лише діагностика фізичного стану здоров'я, а й урахування їхнього психологічного стану [25].

Виділяючи фактори, що призводять до розвитку больового синдрому спини, важливо спочатку розглянути психосоматичні механізми взагалі больових синдромів.

Психічні порушення можуть сприяти розвитку больових синдромів у декількох варіантах: у рамках істеричного або іпохондричного розладу, у поєднанні з депресією, тривогою і при психотичних станах. Біль нерідко виявляється у хворих з демонстративно-іпохондричними розладами й у багатьох випадках слугує єдиним проявом психологічного дистресу. Як правило, хворі, не здатні розпізнати наявність психологічного конфлікту, висловлюють свої емоційні переживання у вигляді болю або інших соматичних симптомів і класифікуються як соматоформні розлади. Такі пацієнти можуть несвідомо перебільшувати свої симптоми, щоб переконати лікаря в тому, що він має справу із серйозним захворюванням. Нерідко хворі відчувають суттєве полегшення, як тільки лікар установлює діагноз конкретного захворювання, за умови що воно не є прогресуючим і має добрий прогноз [26-28].

Больовий синдром часто може бути проявом депресії. У 30-40\% пацієнтів з больовим синдромом діагностується депресія [29].

Виділяють 3 можливі механізми взаємозв'язку болю й депресії: довгостроково наявний больовий синдром призводить до розвитку депресії; депресія передує виникненню болю й нерідко є її першим проявом; i, нарешті, депресія і біль розвиваються незалежно один від одного й існують паралельно. У контексті психосоматичного підходу ми розглядаємо депресію як фактор виникнення больового синдрому, тобто депресія первинна - біль вторинний [30].

$€$ припущення, що наявна в пацієнта депресія може рано чи пізно призвести до виникнення того чи іншого больового синдрому, так званого синдрому «депресія-біль». Так, спеціальне опитування дало змогу виявити в пацієнтів, які страждають на біль різної локалізації, певний рівень депресії ще до появи перших больових скарг. Тобто депресія була первинна, і біль 3'явилася пізніше [31; 32].

Найбільш імовірно, що депресія $є$ найважливішим фактором для розвитку болю і трансформації епізодичних болів у хронічні.

Навіть залишаючи осторонь питання про первинність і вторинність депресивних розладів у хворих з больовими синдромами, очевидно, що депресія $€$ найважливішим компонентом багатьох хронічних больових станів і потребує лікування. Варто підкреслити очевидний зв'язок між депресивним настроєм і показниками больової чутливості. В екс- 
периментах показано, що при моделюванні депресивного фону настрою (прочитання текстів відповідного змісту) у випробовуваних знижувалася толерантність до холодового навантаження, при цьому показники інтенсивності больових відчуттів (за даними візуальної й вербальної аналогових шкал) залишалися незмінними. Навпаки, поліпшення настрою супроводжувалося підвищенням стійкості до холодового навантаження. Висунуто припущення, що фон настрою швидше впливає на поведінковий компонент відповіді на больовий стимул, ніж на інтенсивність больових відчуттів, тобто визначає здатність справлятися з болем [33-37].

Клінічно негативний вплив депресії на больовий синдром може проявлятися збільшенням інтенсивності і тривалості болю, тобто істотним навантаженням клінічної картини, виникненням або посиленням наявного м'язового напруження, дисомнії, а також появою або посиленням болю в період нічного сну, обтяженням перебігу міжбольового періоду (поява астенії, апатії, психовегетативних і психосоматичних порушень) [35].

Серед різних поглядів на тісний зв'язок болю й депресії найбільш визнаними $є$ уявлення про загальні нейрохімічні механізми цих двох феноменів. Показано також, що при депресії полегшується сенсорна передача болю через соматичне фокусування - підвищену увагу до больової зони. Депресивний стан зумовлює специфічну больову поведінку пацієнта з болем та істотно обмежує вибір стратегій подолання болю, 3 яких найбільш часто зустрічається катастрофізація. У результаті пацієнти починають сприймати біль як стан, що загрожує їхньому здоров'ю або навіть життю, стають ще більш депресивними. У кінцевому підсумку, вони втрачають віру в можливість подолання больової проблеми й надію на одужання, розглядають своє майбутнє як похмуре й безнадійне, повністю відмовляються від боротьби. У пацієнтів, які страждають больовим синдромом спини та депресією, як правило, порушується соціальна й професійна адаптація, а якість життя виявляється істотно зниженою [26; 38-40].

Індивідуальні відмінності в реагуванні пацієнтів на біль часто пов'язують із рівнем тривожності індивідуума. Клінічні спостереження й дослідження із застосуванням психометричних тестів показують наявність тісного зв'язку між тривогою та депресією, що зумовлено схожими нейромедіаторними змінами в мозку при цих станах. Так, показано, що частота депресивних розладів, що не супроводжуються тривогою, украй низька та що поєднання тривоги й депресії не може бути випадковим збігом. Дані низки досліджень дають змогу припускати, що серед цих двох станів депресія є більш значущою для якості життя пацієнтів із болем [31; 38; 41-43].

Також розвитку больового синдрому в спині можуть сприяти сімейні, соціально-економічні та культурологічні фактори, пережиті в минулому життєві події, а також особливості особистості хворого. Зокрема, спеціальне опитування пацієнтів з больовим синдромом показало, що їхні найближчі родичі часто страждали від больових відчуттів. У таких «больових сім'ях» у декількох поколіннях може формуватися специфічна модель реагування на біль. Показано, що в дітей, батьки яких часто скаржилися на біль, частіше, ніж у «небольових» сім'ях, виникали різні больові епізоди. Крім того, діти, як правило, переймали «болючу» поведінку своїх батьків. Пережиті в минулому події, особливо фізичне або сексуальне насильство, також можуть мати значення для виникнення в подальшому больового синдрому. Особи, що займаються важкою ручною працею, більш схильні до розвитку болю, часто перебільшують свої болючі проблеми, прагнучи отримати інвалідність або легшу роботу. Показано також, що чим нижчий культурний та інтелектуальний рівень пацієнта, тим вища ймовірність розвитку в нього «психогенних» больових синдромів і соматоформних розладів [44-47].

Психотип і структура особистості, яка формується з дитинства та, як правило, обумовлена генетично й культурологічно, $є$ в основному стабільною характеристикою, властивою кожному індивідууму, у цілому зберігає своє ядро після досягнення зрілого віку. Саме особливості особистості визначають реакцію людини на біль і її «больову» поведінку, здатність переносити больові стимули, спектр емоційних відчуттів у відповідь на біль і способи її подолання.

Наприклад, виявлена достовірна кореляція між переносимістю болю (больовим порогом) ітакими рисами особистості, якінтра- й екстравертність і невротизація (невротизм). Екстраверти під час больових відчуттів більш яскраво висловлюють свої емоції та здатні ігнорувати больові сенсорні впливу. Водночас невротичні й інтравертивні (замкнуті) індивідууми «страждають у тиші» та виявляються більш чутливими до будь-яких больових подразників. Крім того, люди, які володіють оптимістичним поглядом на життя, відрізняються більшою толерантністю до болю, ніж песимісти [48-51].

3 позиції психосоматики больовий синдром спини також розглядають як порушення здоров'я, при яких відбувається соматизація психологічних переживань, коли власний організм, захищаючи душевну рівновагу, тим самим порушує вертебральну рівновагу й з'являється біль у спині, тобто порушується гармонія тілесного здоров'я [52]. 
На фізичному рівні будь-яка негативна емоція рефлекторно «стискає» наше тіло. Якщо подібна реакція відбувається періодично, то формується «звичний спазм». 3 точки зору остеопатії порушується рухливість тканин організму, щоб не викликати негативної й витісненої емоційної реакції.

Локалізація подібного порушення дуже індивідуальна, може залежати від типу емоції, від причини ії виникнення, від індивідуальних особливостей організму, характеру, виховання, оточення й від особливостей ситуації, у яку потрапляє людина.

Поступово формується патологічний ланцюжок: стимул (зовнішня ситуація, думка) - емоція - тілесна реакція. Будь-які схожі переживання (спогади, запахи, зовнішні подразники, емоції) викликають активізацію нейроцитів на сформованій нейропсихофізіологічній дузі та повертаються звичні страждання тіла.

Часто наслідки будь-яких вертебральних конструкцій виражаються у вигляді хронічного больового синдрому, який може локалізуватися в будь-яких частинах тіла. У таких випадках у пацієнта можуть з'являтися хворобливі відчуття, походження яких не може пояснити сучасна медицина, формується «замкнуте коло».

Таким чином, якщо враховувати й психологічну частину в патогенезі болю в спині, стає зрозумілою недостатня ефективність суто соматичного лікування. Підключення психотерапевтичних методів лікування до соматичних може виявитися більш ефективним. Коли до психотерапевтичного лікування додається остеопатичне, удається ширше дивитися на проблематику та шанси на одужання можуть збільшитися.

Висока актуальність питання лікування больового синдрому в спині зумовлена тим, що біль у спині $€$ другою за частотою причиною звернення до лікаря після респіраторних захворювань і третьою за частотою причиною госпіталізації. Близько $20 \%$ дорослого населення страждають від періодично повторюваного болю в спині, тривалістю від 3 днів і більше. Серед них у $80 \%$ під впливом лікування біль проходить протягом 1 міс.

Найчастіше болями в спині страждають люди працездатного віку - від 30 до 45 років. Саме в цьому віковому періоді болю в спині $€$ однією 3 найбільш частих причин утрати працездатності. Біль у спині - проблема міждисциплінарна, так як може спостерігатися в клінічній картині низки соматичних, неврологічних і психічних захворювань [17].

Наявні методи лікування больового синдрому в спині більш стосуються соматичного складника. 3 позиції лікування цього синдрому соматичними методами процес курації фундаментально повинен бути спрямований на поліпшення кровопостачання та інервації паравертебральних відділів, поліпшення стану та рухливості міжхребцевих дисків, глибоких м'язів спини і нервів.

Виділяють такі види терапії при больовому синдромі спини:

- медикаментозне лікування;

- міофасціальна мануальна терапія;

- акупунктура;

- фізична терапія;

- ЛФК в домашніх умовах;

- остеопатичне лікування болю.

Медикаментозне лікування застосовується при захворюваннях опорно-рухового апарату, а також для лікування гострого та хронічного болю в хребті. Швидко знімає запалення й больовий синдром знеболювальний ефект, тобто $€$ симптоматичним і не впливає на всі ланки патогенезу, не усуває основну причину цього синдрому. Тому медикаментозне лікування дає швидкий, але нетривалий ефект [53; 54].

Метод міофасціальної мануальної терапії - це розтягнення й розслаблення проблемних ділянок спини з використанням методик постизометричної релаксації та рефлексотерапевтичного масажу, трастів, може показувати певну ефективність, яка не триває досить довго й симптоми можуть повертатися знову [55].

Акупунктура направлена на розширення дрібних судин і посилення кровотоку в зоні впливу, що сприяє усуненню тригерних точок, хоча сьогодні цей вид терапії не показує заявленої ефективності [20; 56-60].

Фізичну терапію зазвичай використовують для покращення крово- та лімфообігу, знеболювання, загального зміцнення організму, коригувальної дії на хребет і тулуб, зміцнення м'язів спини, нормалізації функції нервово-м'язового комплексу, підвищення адаптаційних можливостей.

Так, серед фізичних методів застосовують електоростимуляцію ослаблених м'язів спини, діадинамотерапію, електрофорез анетезуючої суміші кальцію та фосфору, УВЧ-терапію, ультрафіолетове опромінювання, парафіно-озокеритні аплікації. Тобто фізична терапія спрямована на покращання загального стану організму, не є прицільною, спрямованою суто на патогенетичні ланки больового синдрому в спині [61-63].

Лікувальна гімнастика - ЛФК - комплекс фізичних вправ, спрямованих на лікування, реабілітацію та профілактику захворювань опорно-рухового апарату, допомагає зміцнити м'язовий корсет спини, збільшити рухливість суглобів, усунути дисбаланс м'язів і зв'язок, знизити навантаження на хребет, а також комплексно оздоровити організм. Однак разом із фізичними методами не є спрямованою на патогенетичні ланки, тому ефект може бути 
слабким і нетривалим в умовах використання цього методу відокремлено від інших [64].

Остеопатичні методи курації болю - метод ручної остеопатичної діагностики, заснований на здатності фахівця визначати напруження м'язів, натяг фасціальних оболонок і сухожиль, зміщення кісток і порушення ритмів руху внутрішніх органів, причини захворювання, які можуть маскуватися під різні реакції тіла, і синдроми, наприклад, локальні болі, неврологічні порушення [65; 66].

У процесі огляду остеопат коригує суглоби, хребет і відновлює рухливість у них, знімає м'язові спазми, покращує рух крові й лімфи, що дає змогу зняти біль не лише як наслідок, а іноді і як причину. Терапія проходить м'яко й без різких інвазивних втручань, що $є$ важливим моментом для мотонейронів для курації больового синдрому при міофасціальному синдромі.

Остеопатичний підхід розглядає больовий синдром як наслідок збою тривимірної роботи м'язово-скелетної, нервової та психічної системи, яка постійно адаптується до нових обставин перебування й розвитку в навколишньому середовищі, тобто він $є$ нібито місточком між соматичним і психологічним підходом.

Остеопатичне лікування аналізує проблеми як порушення всього організму, а не окремого органу або конкретної системі. Виниклий симптом є тільки наслідком прихованої недуги. Часто справжня причина недуги криється зовсім не там, де її шукають. Іноді проблеми зі здоров'ям викликають на перший погляд абсолютно не взаємопов'язані між собою органи. Іншими словами, у поперекових болях іноді може бути винна навіть щелепа, а в зубному болю - проблеми зі стопою. Хоча це звучить дивно й навіть смішно, але в організмі все більш взаємопов'язане, ніж ми думаємо [67].

Остеопатична методика лікування болю полягає в спрямованості на запуск прихованих ресурсів організму для самозцілення. Виділяють такі види остеопатичної терапії:

- вісцеральну - для вирішення проблем органів грудинно-брюшної діафрагми й органів малого тазу, моторно-евакуаторної функції кишківника, перистальтики, секреторної Функції;

- структуральну - для вирішення проблем опорно-рухового апарату та його болю, порушення постави, дегенеративні зміни суглобів, обмежень рухів кінцівок і спазмів що спонукають біль. Цей вид має велику ефективність при болі в спині внаслідок м'язово-фасціального синдрому. М'яка мобілізація м'яза спини та/ або його зв' язкового апарату не викликає активізацію мотонейронів і в обхід гамма-петлі вдається відразу вплинути на першопричину болю;

- краніо-сакральну - ефективно покращує кровообіг головного мозку, усуває голов- ний біль, відновлюється рухливість кісток тазу, суглобів хребта, зменшується напруження мозкових мембран, нормалізується функція нервової системи [68-73].

Таким чином, лікування пацієнтів наведеними методами соматичної терапії дає позитивну динаміку, але не завжди та не прологонговано, що свідчить про те, що соматичні методи не враховують дуже важливу ланку патогенезу - психологічну.

Психокорекційні методи, на відміну від соматичних, зазвичай допомагають подолати катастрофізацію болю, «обмежувальну» поведінку, симптоми тривоги й депресії, поліпшити якість життя, що впливає на психічну етимологію болю в спині.

За останні кілька років відбувається збільшення кількості клінічних досліджень із цього напряму. Так, із 2011 по 2018 рр. проведено 24 контрольовані дослідження. Провідними психологічними методами для лікування пацієнтів з больовим синдромом визнаються когнітивно-поведінкова терапія (далі - КПТ) і майндфулнес (терапія усвідомленість) [74; 75].

Автори недавнього міжнародного огляду 15 посібників 3 діагностики та лікування больового синдрому зробили висновок, що більшість (82\%) керівництв рекомендують використовувати психокорекційні методи в лікуванні хворих на больовий синдром [53].

Психокорекційні методи допомагають змінити уявлення пацієнтів про фізичну активність і пов'язані з нею очікування, підвищити їхню прихильність до лікувальної гімнастики й інших видів фізичних вправ (наприклад, плавання, водної аеробіки, пішої ходьби, занять фітнесом) [56; 57; 76].

Використання психокорекційних методів може збільшувати тривалість досягнутого клінічного ефекту після лікування [19; 20].

Виходячи з психосоматичної теорії больового синдрому в спині, важливе місце в його лікуванні займають психокорекційні та психотерапевтичні методи. Саме вони допомагають пацієнтам не тільки впоратися з катастрофізацією болю, підвищити повсякденну активність і знизити ймовірність рецидиву захворювання, а й розв'язати наявні внутрішньоособистісні конфлікти, які лежать в основі формування больового синдрому в спині. Саме тому разом із вищенаведеними КПТ та майнфулднес використовують особистісно орієнтовані психодинамічні методи психотерапії [77; 78].

У цілому виділяють такі психотерапевтичні методи, що використовують для лікування больового синдрому в спині:

1. Психосинтез - динамічна корекція психічного життя людини з урахуванням певного підходу до будови та функціонування внутрішнього світу. 
2. Терапія, сфокусована на вирішенні. Принципово не фокусується на пошуку причин дискомфорту пацієнта, а займається пошуком і реалізацією ресурсів для його подолання.

3. Позитивна інтерпретація симптомів дає змогу знайти позитивний початок у хвороби й поступово змінює точку зору на свою хворобу.

4. Гештальт-терапія. Розблокування та стимулювання розвитку людини, реалізація її можливостей і прагнень за рахунок створення внутрішнього джерела опори й оптимізації процесів саморегуляції, робота з почуттями пацієнта.

5. Когнітивно-поведінкова. Психопатологічні та психосоматичні розлади є наслідком неточної оцінки подій. При зміні оцінки цих подій відбувається зміна стану, виникає можливість по-іншому реагувати на ситуації, що викликають напади паніки або агресії.

6. Символодрама (метод кататимного переживання образів).

7. Транзактний аналіз. Аналіз у структурі особистості его-станів, сукупності пов'язаних між собою поводжень, думок і почуттів як способу прояву особистості в цей момент.

8. Ортодоксальний психоаналіз. Аналіз витіснених у несвідоме несприятливих емоцій (агресія, сексуальний потяг), які проявляються у вигляді символів.

9. Психодрама. Груповий процес, у якому використовується інструмент драматичної імпровізації для вивчення внутрішнього світу пацієнта, формування нових відносин і моделей поведінки, реально наближених до життя.

10. Тілесно-орієнтована психотерапія. Робота з невирішеними емоціями і травматичними спогадами пацієнта, які внаслідок механізмів психологічного захисту знаходять вихід через тіло.

11. Нейролінгвістичне програмування.

12. Сімейна психотерапія. Модифікація відносин між членами сім'ї як системи.

13. Креативна візуалізація. Використання творчої, керованої візуалізації для формування нейропсихологічних процесів.

14. Арт-терапія мистецтвом. Метод дає змогу експериментувати з почуттями, досліджувати й виражати їх на символічному рівні.

15. Танцювально-рухова психотерапія. Метод, у якому рух $€$ способом переробки інформації, самопізнанням, самовираженням і розвитком.

16. Копінг-поведінка-форма поведінки, яка відображає готовність індивіда вирішувати життєві проблеми. Це поведінка, що спрямована на пристосування до обставин і передбачає сформоване вміння використовувати певні засоби для подолання емоційного стресу. При виборі активних дій підвищується ймовірність усунення впливу стресорів на особистість. Особливості цього вміння пов'язані з «Я-кон- цепцією", локусом контролю, емпатією, умовами середовища. За уявленнями Маслоу, копінг-поведінка протиставлена експресивній поведінці.

17. Майндфулнес (терапія усвідомленості, англ. Mindfulness - усвідомленість, просвітлення, безоцінне усвідомленням) - психологічний метод лікування хронічного болю й емоційних порушень, заснований на медитації.

18. Психоаналітична терапія.

Психологічні методи курації потрібні як для того, щоб змінити ставлення пацієнта до хвороби й фізичного навантаження, так і для впливу на психосоматичний складник цього синдрому, а саме невирішеного психологічного конфлікту [79-98].

Висновки. Таким чином, на фоні добре розробленої схеми соматичного лікування больового синдрому в спині існує необхідність додання психокорекційних і психотерапевтичних методів і створення комбінованого протоколу для впливу на всі ланки патогенезу цього розладу.

Комбінований протокол повинен ураховувати міждисциплінарний підхід до лікування, який включатиме не тільки освітню програму, психокорекційні та психотерапевтичні методи, наявні соматичні методи, а й остеопатичні методи, роль яких недооцінювалася дотепер.

Психосоматично-остеопатичний підхід може виявитися дуже ефективним, так як це дає змогу розглядати організм людини як єдине ціле. Методи остеопатичного лікування дають можливість запустити саморегуляцію організму, а також допомагають пацієнту відновити емоційний баланс, разом із психотерапевтичним та соматичним лікуванням вплинути на всі ланки патогенезу.

Таким чином, пропонування міждисциплінарної моделі терапії, де біль розглядається не просто як відчуття, в основі якого лежить пошкодження тканини або органу, а комплекс мультимодальних переживань, може стати новим етапом у лікуванні больового синдрому спини й показати більшу ефективність порівняно з наявними методами. Цей підхід пропонує не тільки вивчати моторні та сенсорні механізми болю, а й брати до уваги когнітивні, афективні й поведінкові характеристики, які визначають перенесення болю, больову поведінку та здатність справлятися з больовим синдромом.

Більш того людина - істота соціальна, тому останнім часом особливо важливим стає вивчення біомеханічної та біопсихосоціальної концепції болю. Малорухливий спосіб життя, статична сидяча робота з дня в день погіршують якість опорно-рухового апарату кожного з нас і згодом призводять до виникнення больового синдрому. Саме тому це питання $€$ архіважливим і потребує подальшого вивчення. 
Перерахована вище методологія соматичної (мануально-фізичної та медикаментозної) терапії больового синдрому спини не є панацеєю в разі виникнення болю, вона усуває симптоми болю недостатньо, впливаючи на першопричину, тому ефект вид соматичної терапії короткотривалий.

Соматичні методи лікування недосконалі, тому що етіологія захворювання $€$ не тільки суто фізіологічна, а й психогенна. Тому $€$ необхідність використання психокорекційних інструментів для вдосконалення процесу лікування больового синдрому спини та підвищення ефективності в лікуванні.

Також біль необхідно розглядати як особистісне переживання, що виникає під впливом не лише фізичної патології, а й особистісного погляду на захворювання та попереднього досвіду. Такі психологічні фактори, як страх, тривога, депресія, безумовно, впливають на формування та сприйняття болю. Відповідно до цієї концепції, біль - це результат динамічної взаємодії біологічних, психологічних і соціокультурних факторів.

Крім того, невирішений внутрішній конфлікт може стати причиною виникнення болю в спині та хвороб, асоційованих із болем, тобто психосоматичний механізм його виникнення.

Таким чином, якщо розглядати біль у спині як психосоматичне захворювання, ми не зможемо повноцінно допомогти таким пацієнтам, не впливаючи на психологічну ланку патогенезу захворювання. Стійкий позитивний результат лікування можливий тільки із застосуванням комплексної терапії.

Більш того, неправильно підібраний метод діагностики або вид терапії й подальші рекомендації при першому звертанні до спеціаліста можуть бути ятрогенним фактором, який заставляє хворого "опускати руки» і зневіритися в подальшому результаті.

Психосоматичний підхід до больового синдрому в спині потребує від фахівця володіння суміжними знаннями та досвідом декількох спеціалізацій або партнерства з іншими спеціалістами для більш ефективного діагностування й терапії цього синдрому.

Через недостатність даних щодо діагностики та лікування больового синдрому спини ми вважаємо за необхідне більш поглиблене вивчення питання психологічних аспектів, що впливають на етіологію й патогенез болю, динаміку лікування, як результат, створення нового психосоматико-остеопатичного підходу.

\section{ЛITEPATУPA:}

1. Global, regional, and national incidence, prevalence, and years lived with disability for 310 diseases and injuries, 1990-2015: a systematic analysis for the Global Burden of Disease Study 2015. GBD 2015 Disease and Injury Incidence and Prevalence Collaborators. Lancet. 2016. № 388 (10053). P. 1545-1602.

2. Koes B.W., van Tulder M.W., Thomas S. Diagnosis and treatment of low back pain. BMJ. 2006. № 332 (7555). P. 1430-1434.

3. Central pain processing in chronic tension - type headache / K. Lindelof, J. Ellrich, R. Jensen et al. Clin. Neurophysiol. 2009. № 120 (7). P. 1364-1370.

4. Tavee J.O., Levin K.H. Low back pain. Continuum. 2017. № 23 (2). P. 467-486.

5. Petersen T., Laslett M., Juhl C. Clinical classification in low back pain: best-evidence diagnostic rules based on systematic reviews. BMC Musculoskelet Disord. 2017. № 18 (1). P. 188.

6. Хронические болевые синдромы пояснично-крестцовой локализации: значение структурных скелетно-мышечных расстройств и психологических фракторов / Е.В. Подчуфрарова, Н.Н. Яхно, В.В. Алексеев и др. Боль. 2003. № 1. С. 38-43.

7. Психиатрические, психологические и неврологические характеристики больных с хроническими болями в спине / Ю.А. Александровский, Н.Н. Яхно, А.С. Аведисова и др. Журн неврол и псиxuamp. 2002. № 103 (4). C. 26-31.

8. Gatchel R.J., Rollings K.H. Evidenceinformed management of chronic low back pain with cognitive-behavioral therapy. Spine J. 2008. № 8. C. 40-44.

9. Morone N.E., Rollman B.L., Moore C.G., et al. A mind-body program for older adults with chronic low back pain: results of a pilotstudy. Pain Med. 2009. № 10 (8). C. 1395-407.

10. Шток В.Н. Головная боль. 2-е издание. Москва : ООО «Медицинское инсрормационное агентство», 2007. 472 C.

11. Справочник по фрормулированию клинического диагноза болезней нервной системы / под ред. В.Н. Штока, О.С. Левина. Москва : ООО МИА, 2006. $520 \mathrm{c}$.

12. Chou R., Qaseem A., Snow V., et al. Diagnosis and treatment of low back pain: a joint clinical practice guideline from the American College of Physicians and the American Pain Society. Ann Intern Med. 2007. № 147. P. 478-91.

13. Іванічев Г.А. Патогенетичні аспекти формування та проявлення класичних больових м'язових синдромів. Мануальна терапія. 2009. № 3 (35). C. 4-5.

14. Беглярова М., Орлова О. Вторичный миофасциальный болевой синдром при невралгии тройничного нерва. Врач. 2007. № 36. С. 105-107.

15. Вальтер Дэвид С. Прикладная кинезиология. 2-е издание. Санкт-Петербург, 2011. 644 с.

16. Годзенко А.А., Бадокин В.В. Локальная терапия миофасциального болевого синдрома. РМЖ. Ревматология. 2007. № 26. С. 1998-2003.

17. Van Tulder M.W., Touray T., Furlan A.D. et al. Muscle relaxants for non-specific low back pain. Cochrane Database Syst Rev. 2003. № 2.

18. Иваничев Г.А. Патогенетические аспекты формирования и проявления классических болевых мышечных синдромов. Мануальная терапия. 2009. № 3 (35). C. 3-12. 
19. Парфенов В.А., Головачева В.А. Хроническая боль и ее лечение в неврологии. Москва:ГЭОТАР-Медиа, 2018. 288 с. [Parfenov V.A., Golovacheva V.A. Khronicheskaya bol' i ee lechenie $v$ nevrologii [Chronic pain and its treatment in neurology]. Moscow : GEOTARMedia, 2018. 288 p. (In Russ.)

20. Сучасні аспекти діагностики та лікування вертеброгенних больових синдромів / А.А. Козелкін, С.А. Козелкіна, І.Г. Віцина та ін. Міжнародний неврологічний журнал. 2006. № 1 (5). С. 82-85.

21. Otis J.D. Managing chronic pain: a cognitivebehavioral therapy: therapist guide. 1st ed. New York : Oxford University Press; 2007. 114 p.

22. Гурак С.В., Парфенов В.А., Борисов К.Н. Мидокалм в комплексной терапии острой поясничной боли. Боль. 2006. № 3. С. 27-30.

23. Walsh D.A., Radcliffe J.C. Pain beliefs and perceived physical disability of patients with chronic low back pain. Pain. 2002. № 97 (1-2). P. 23-31.

24. Волошин В.М. Посттравматическое стрессовое расстройство. Феноменология, клиника, систематика, динамика и современные подходы к психофрармакотерапии. Москва: Анахарсис, 2005. 200 с.

25. Ostelo R.W., Van Tulder M.W., Vlaeyan J.W. et al. Behavioral treatment for chronic low back pain (review). The Cochrane Library. 2005. № 4. P. 1-25.

26. Андреев И.Л., Березанцев А.Ю. Взаимосвязь психического и соматического здоровья человека Человек. 2010. № 2. С. 135-142.

27. Андреев И.Л., Назарова Л.Н. Психиатрия как предмет образования и просвещения. Вопр. философрuи. 2011. № 10.

28. Психические расстройства в клинической практике / под ред. А.Б. Смулевича. Москва : МЕДпресс, 2011. С. 13.

29. Смулевич А.Б. Депрессии при соматических и психических заболеваниях. Москва, 2003.

30. Смулевич А.Б. Депрессии в общей медицине. Москва : Медицинское информационное агентство, 2001. 782 c.

31. Смулевич А.Б. Психические расстройства в клинической практике. Москва : МЕД-пресс инорорм, 2011. 720 с.

32. Смулевич А.Б., Иванов С.В., Самушия М.А. $\mathrm{K}$ проблеме биполярных афффективных расстройств, заимствующих ритм соматического заболевания. Психические расстройства в общей медицине. 2012. № (2). C. 4-11.

33. Палеев Н.Р., Краснов ВН. Взаимосвязь психосоматики и соматопсихиатрии в современной медицине. Клиническая медицина. 2009. № 87 (12). C. 4-7.

34. Хронический стресс и депрессия у больных ревматоидным артритом / А.Е. Зелтынь и др. Социальная $и$ клиническая психиатрия. 2009. № 19 (2). C. 69-75.

35. Cross-Disorder Group of the Psychiatric Genomics Consortium. Identification of risk loci with shared effects on five major psychiatric disorders: a genome-wide analysis. Lancet. 2013. № 381 (9875). C. 1371-1379.

36. Краснов В.Н. Проблема современной диагностики депрессий. Журнал неврологии и психиатрии им. С.С. Корсакова. 2012. № 11 (2). С. 3-10.
37. Hoffman B.M., Chatkoff D.K., Papas R.K. et al. Meta-analysis of psychological interventions for chronic low back pain. Health Psychol. 2007. № 26. C. 1-9.

38. Вознесенская Т.Г. Хроническая боль и депрессия. Фарматека. 2008. № 6 (160). С. 10.

39. Краснов В.Н. Психоорганический синдром как проблема нейропсихиатрии. Доктор.Ру. 2011. № 4 (63). C. 34-42.

40. Guzman J., Esmail R., Karjalainen K. et al. Multidisciplinary bio-psycho-social rehabilitation for chronic low back pain. The Cochrane Database of Systematic Reviews. 2001. № 1.

41. Воробьева О.В. Возможности антидепрессантов в лечении хронической боли. Фарматека. 2007. № 12 (146). С. 92-97.

42. Осипова В.В. Мигрень: клиникопсихологический анализ, качество жизни, коморбидность, терапевтические подходы : дисс. ... докт. мед. наук. Москва, 2003.

43. Газарова Е. Психология телесности. Москва : Институт общегуманитарных исследований, 2002. С. 74-85.

44. Сергеева Л.С. Телесно-ориентированная психотерапия : хрестоматия. Санкт-Петербург : РОФ «Практическая психотерапия», 2000. С. 255-264.

45. Смулевич А.Б. Депрессии при соматических и психических заболеваниях. Москва, 2003.

46. Kandel E.R. Биология и будущее психоанализа: новый взгляд на концептуальную базу для психиатрии. Обзор современной психиатрии. 2000. Вып. 6. С. 6.

47. Ковалев С.В. Основы нейротрансформинга или психотехнологии управления реальностью. Москва : Профит Стайл, 2012. 224 с.

48. Эллис А., Драйден У. Практика рациональноэмоциональной поведенческой терапии. Санкт-Петербург : Речь, 2002.

49. Gatchel R.J., Rollings K.H. Evidenceinformed management of chronic low back pain with cognitive-behavioral therapy. Spine J. 2008. № 8. P. $40-44$

50. Бек Д.С. Когнитивная терапия: полное руководство. Москва : ООО «И.Д. Вильямс», 2006.

51. Голубєв В.Л., Данилов А.Б., Вейн А.М. Психосоціальні чинники, гендер і біль. Журнал неврології $і$ психіатрії. 2004. Т. 104 (11). С. 70-73.

52. Смулевич А.Б. Депрессии при соматических и психических заболеваниях. Москва, 2003.

53. Годзенко А.А., Бадокин В.В. Локальная терапия миосрасциального болевого синдрома. РМЖ. Ревматология. 2007. № 26. С. 1998-2003.

54. Дадашева М.Н., Агафонов Б.В., Шевцова Н.Н. Алгоритм терапии миофасциального болевого синдрома. Трудный пациент. 2013. № 11. С. 47-50.

55. Психиатрические, психологические и неврологические характеристики больных с хроническими болями в спине / Ю.А. Александровский, Н.Н. Яхно, А.С. Аведисова и др. Журн неврол и псиxuamp. 2002. № 103 (4). C. 26-31.

56. Field B.J., Swarm R.A. Chronic pain (Advances in psychotherapy - evidence-based practice). Hogrefe, 2008.

57. Осипова В.В. Мигрень: клинико-психологический анализ, качество жизни, коморбидность, 
терапевтические подходы : дисс. ... докт. мед. наук. Москва, 2003.

58. Парфенов В.А., Иванова М.А. Ведение пациентов с болью в спине врачами общей практики. Медицинский совет. 2018. № 1. С. 112-117.

59. Вознесенская Т.Г. Хроническая боль и депрессия. Фарматека. 2008. № 6 (160). С. 10-15.

60. Подчуфарова Е.В., Яхно Н.Н. Боль в спине. Москва : ГЭОТАР-Медиа, 2010. 368 с.

61. Dionne C.E., Von Korff M., Deyo R.A. et al. Formal education and back pain: a review. J Epidemiol Com Health. 2001. № 55. P. 455-68.

62. Мухін В.М. Фізична реабілітація. Розділ 6 : Фізична реабілітація при больовому синдрому при вадах постави. Москва, 2015. С. 387.

63. Вертеброгенні больові синдроми попереково-крижового відділу хребта та їх лікування із застосуванням вітамінів групи В / С.М. Віничук, І.І. Бедрій, П.П. Уніч та ін. Український медичний часопис. 2007. № 6 (62).

64. Азарова Е.К., Балякин С.А., Манихин В.В. Краниальная мануальная терапия в восстановительном лечении больных с последствиями закрытой черепно-мозговой травмы. Бюллетень МПОМТ. 2001. № 3. C. 34-35.

65. Батов А.Г. Оценка эфрфективности применения краниосакральных техник мануальной терапии в лечении больных с закрытыми черепно-мозговыми травмами. Мануальная терапия. 2009. № 4 (36). C. 21-26.

66. Мохов Д.Е., Новосельцев С.В., Мирошниченко Д.Б. Остеопатия. Структуральный раздел. Артикуляционные техники. Санкт-Петербург : МАПО, 2010. 36 c.

67. Магун Г.И. Остеопатия в краниальной области. Санкт-Петербург : Меридиан-С, 2010. 336с.

68. Животов В.А., Радченко О.А. Способ восстановления и оздоровления пациента с использованием балансировки мышечно-фрасциальновисцеральных цепей подходом через основание черепа. Патент на изобретение C12611908RU. Москва, 2015. 17 c.

69. Franke $H$. et al. Osteopathic manipulative treatment for low back and pelvic girdle pain during and after pregnancy: A systematic review and meta-analysis. J. Bodyw. Mov. Ther. 2017. № 21 (4). P. 752-62.

70. Новосельцев С.В. Введение в остеопатию. Мягкотканные и артикуляционные техники : практическое руководство для врачей. Санкт-Петербург : Фолиант, 2005. 252 с.

71. Торстон Л. Практика краниосакральной остеопатии. Санкт-Петербург : Меридиан-С, 2008. 509 с.

72. Хебген Э. Висцеральная остеопатия. Принципы и техники / Э. Хебген. Москва : Эксмо, 2013. $240 \mathrm{c}$.

73. Vitoula K., Venneri A., Varrassi G., et al. Behavioral therapy approaches for the management of low back pain: An up-to-date systematic review. Pain Ther. 2018. № 7 (1). P. 1-12.

74. Подчуфарова Е.В. Значение скелетномышечных расстройств и психологических фракторов в развитии хронических болевых синдромов пояснично-крестцовой локализации : дисс. ... канд. мед. наук. Москва, 2002. 182 с.
75. Kamper S.J., Apeldoorn A.T., Chiarotto A., et al. Multidisciplinary biopsychosocial rehabilitation for chronic low back pain: Cochrane systematic review and meta-analysis. BMJ. 2015. № 350. P. 444.

76. Михайлов Б.В. Проблема оценки эфффективности и качества оказания психотерапевтической помощи. Український вісник психоневрології. 2010. Том 18. Вип. 3 (64). С. 137-138.

77. Valet M., Sprenger T., Boecker H. et al. Distraction modulates connectivity of the cingulo-frontal cortex and the midbrain during pain - an fMRI analysis. Pain. 2004. № 109. P. 399-408.

78. Григорьева В.Н., Тхостов А.Ш. Психологическая помощь в неврологии. Н. Новгород : Изд-во НГМА, 2009.

79. Пушко Є.І. Основні техніки з використанням уяви в когнітивно-поведінковій психотерапії. Психологічні координати розвитку особистості: реалії i перспективи : матеріали V Міжнар. наук.-практ. онлайнконф. (м. Полтава, 27-28 квітня 2020 р.). Полтава, 2020. С. 137-140.

80. Gatchel R.J., Rollings K.H. Evidenceinformed management of chronic low back pain with cognitivebehavioral therapy. Spine J. 2008. № 8. P. 40-44.

81. Абрамов В.В. Уявлення про психологічне благополуччя у третій хвилі когнітивно-поведінкової терапії. Особистісні та ситуативні детермінанти здоров'я : матеріали п'ятої Всеукраїнської науковопрактичної конференції (м. Донецьк, 18 листопада 2020 р.). Донецьк, 2020. С. 7-10.

82. Hoffman B.M., Chatkoff D.K., Papas R.K. et al. Meta-analysis of psychological interventions for chronic low back pain. Health Psychol. 2007. № 26. P. 1-9.

83. Ostelo R.W., Van Tulder M.W., Vlaeyan J.W. et al. Behavioral treatment for chronic low back pain (review). The Cochrane Library. 2005. № 4. P. 1-25.

84. Гуревич П.С. От 3. Фрейда к М. Кляйн. Психология и психотехника. 2013. № 2. С. 111-114.

85. Гуревич П.С. Психоанализ как терапия. Психология и психотехника. 2011. № 12. С. 4-5.

86. Александер Ф. Психосоматическая медицина. Принципы и практическое применение / пер. с англ. Москва : ЭКСМО-Пресс, 2002.

87. Михайлов Б.В., Чугунов В.В., Добровольська О.С. Проблеми клініки, діагностики та психотерапії соматоформних розладів в амбулаторно-поліклінічній практиці за умов індустріального центру (методологія, клініка, епідеміологія та диференційна діагностика). Укр. вісн. психоневрології. 2004. Т. 12. Вип. 1. С. 33-39.

88. Kandel E.R. Биология и будущее психоанализа: новый взгляд на концептуальную базу для психиатрии. Обзор современной психиатрии. 2000. Вып. 6. С. 6.

89. Михайлов Б.В. Проблема оценки эффрективности и качества оказания психотерапевтической помощи. Український вісник психоневрології. 2010. Том 18. Вип. 3 (64). С. 137-138.

90. Марута Н.О. Стан психічного здоров'я населення та психіатричної допомоги в Україні. Нейро News психоневрология и нейропсихиатрия. 2010. № 5 (24). C. 83-90. 
91. Йоргенсен С. Структура характера и шоковая травма. Бюллетень ассоциации телесно-ориентированных психотерапевтов. 2005. № 7. C. 84-95.

92. Малкина-Пых И.Г. Психосоматика : новейший. Москва : Эксмо ; Санкт-Петербург : Сова, 2003. 928 с.

93. Мищенко Н. Тревожные расстройства: прерогатива терапевтов или психиатров? Здоров'я України. 2006. № 13-14 (146-147). C. 1-3

94. Палеев НР, Краснов ВН. Взаимосвязь психосоматики и соматопсихиатрии в современной медицине. Клиническая медицина. 2009. № 87 (12). C. 4-7.
95. Андреев И.Л., Березанцев А.Ю. Взаимосвязь психического и соматического здоровья человека. Человек. 2010. № 2. С. 135-142.

96. Марута Н.О. Стан психічного здоров'я населення та психіатричної допомоги в Україні. Нейро News психоневрология и нейропсихиатрия. 2010. № 5 (24). C. 83-90.

97. Христук О.Л. Сучасні виміри психологічної практики: майндфулнес-підхід. Науковий вісник Львівського державного університету внутрішніх справ. Серія «Психологія». Львів, 2018. Вип. 1. С. 153-161.

98. Швец И. Психоанализ в Украине. Психоаналіз. 2003. № 1. С. 158. 